\title{
Kroppsmasseindeks og vektutvikling: Hvilke forskjeller er det mellom kjønnene?
}

\author{
Sidsel Graff-Iversen ${ }^{1}$ og Henriette Øien ${ }^{2}$ \\ ${ }^{I}$ Statens helseundersøkelser \\ ${ }^{2}$ Statens råd for erncering og fysisk aktivitet \\ Korrespondanse: Sidsel Graff-Iversen, Statens helseundersøkelser, Postboks 8155 Dep., 0033 Oslo \\ Telefon: 22242154 (direkte), 22242100 (sentralbord kl. 09-15) telefax: 22242101 e-post: sgraffi@online.no
}

\begin{abstract}
SAMMENDRAG
Det er klare forskjeller mellom kvinner og menn når det gjelder gjennomsnittlig kroppsmasseindeks (KMI), forekomsten av fedme og undervekt og endring av dette med økende alder. Før 50-60 års alder er gjennomsnittlig KMI lavere hos kvinner enn hos menn og en lavere andel kvinner enn menn har KMI $30 \mathrm{~kg} / \mathrm{m}^{2}$ eller mer (fedme), mens det i høyere alder er omvendt. I alle aldersgrupper er undervekt, slanking og ønske om vektreduksjon mer vanlig blant kvinner enn blant menn. Hos menn stiger gjennomsnittlig KMI fram til 50 års alder, men blant kvinnene er det vist stigning helt fram til 60-70 års alder. Hvorfor er kjønnene ulike når det gjelder under- og overvekt? Selektiv tilvekst og tap av andre vev enn fett - styrt blant annet av kjønnshormoner - forklarer trolig en del. Men både norske data og internasjonale data viser at gjennomsnittlig KMI og andelen som har fedme synker med økende utdanning. Dette er mest uttalt blant kvinner. Holder de "flinke damene" seg slanke fordi de vet at en tynn kropp er særlig viktig nettopp for dem, når det gjelder å være godt ansett og attraktiv i samfunnets høyere lag?

Vektutviklingen var ulik for voksne kvinner og menn i en lang periode i dette århundre. Blant voksne menn har gjennomsnittlig KMI steget jevnt fra 1960-årene fram til i dag. Hos kvinner lå vekten høyt i 1960-årene, men avtok fram til 1975 for så å øke fra omkring 1980. Blant ungdom av begge kjønn finner vi, i de data som foreligger, at gjennomsnittsvekten steg etter krigen, flatet ut i 1950 og gikk ned fra 1960 til 1975, for senere å stige. Hvilke forhold i etterkrigstiden har påvirket kjønnene spesifikt blant voksne, men mer likt blant ungdom? Som mulige årsaker drøftes de ulike trendene for kvinner og menn når det gjelder røyking og overgangen fra tungt til lettere fysisk arbeid.
\end{abstract}

\section{INNLEDNING}

En rapport fra en arbeidsgruppe i regi av WHO konkluderte i 1997 med at forekomsten av fedme globalt viser en økning og at visse forskjeller mellom kjønnene går igjen (1). Overvekt, definert som KMI i området 25 til $29,9 \mathrm{~kg} / \mathrm{m}^{2}$, er vanligere blant menn enn blant kvinner. Men forholdsvis flere kvinner enn menn har fedme, definert som KMI $30 \mathrm{~kg} / \mathrm{m}^{2}$ eller høyere. Videre er fedme et sosialt skjevt fordelt fenomen. De lavere sosiale lag, og særlig kvinner i disse lagene, er mest utsatt. Grupper som utsettes for brå overgang fra knapphet til overflod på næring, er særlig utsatt for å utvikle fedme. På den annen side er unge kvinner i høyere sosiale lag de minst fornøyde med kroppen sin (1). I tråd med dette finnes holdepunkt for at slanking, spiseforstyrrelser og undervekt er mer vanlig hos kvinner enn hos menn (2).

En relativt ny rapport fra Statens råd for ernæring og fysisk aktivitet (SEF) viser at de trekkene vi her har nevnt, gjelder også for Norge (3). Imidlertid viser resultater fra norske helseundersøkelser at hovedtrekkene i vektutviklingen hos voksne kvinner og menn var vesensforskjellig fra 1960-årene til omkring 1980 (4).
Hensikten med denne artikkelen er å diskutere de kjønnsforskjellene vi finner, internasjonalt og nasjonalt, når det gjelder vekt og vektutvikling. Som utgangspunkt vil vi gjengi noen data (materialer, metoder og resultater) nevnt i SEFs rapport (3). I diskusjonen er det rimelig å spørre om KMI er et godt mål for kroppsfett, når man sammenligner på tvers av kjønn og aldersgrupper. Og det er spørsmål om i hvilken grad de ytre faktorene som innvirker på mengde kroppsfett har vært og er kjønnsspesifikke. Kan utviklingen i 1960- og 1970-årene forklares med at forhold som har påvirket vekten, har rammet kvinner og menn på forskjellige tidspunkter? Her drøftes mulige forklaringer uten forsøk på testing av de hypotesene som settes fram. Denne artikkelen tar ikke opp likheter og forskjeller mellom kjønnene når det gjelder helsemessige konsekvenser av over- og undervekt.

\section{NORSKE HELSEUNDERSØKELSER: MATERIALER OG METODER}

Data om høyde og vekt er beskrevet fra skoleundersøkelser i Oslo for perioden 1920-1975 og andre skolebarn i 1970- og 1980-årene (5-9). Folkeskolen i alder 
7-14 år var obligatorisk. Men elevene som gikk videregående skole i tiden 1920-1975 var ikke representative for sine aldersgrupper i en tid da det ikke var vanlig at ungdom - og særlig ikke jenter - fra arbeiderklassen gikk på gymnaset. Også prosjektet Kjenn din kropp gir oss data fra Oslo i 1979 for aldersgruppen 10-15 år (10). Statens ernæringsråds nasjonalt representative utvalgsundersøkelse UNGKOST i 1993 gir selvrapportert høyde og vekt hos 13- og 18-åringer på landsbasis (11). Her var deltagelsen $94 \%$. NORKOST 1993-94 gir tilsvarende informasjon for befolkningen $\mathrm{i}$ alder 16-79 år og har deltagelse på $63 \%$ (12). Ved NORKOST i 1997 var deltagelsen lavere, $54 \%$ (13).

For alder 15 år og eldre finnes data fra skjermbildeundersøkelser i tiden 1963-75 (4). Fremmøte var obligatorisk og lå rundt $80 \%$. Fra 1974-76 finnes data fra helseundersøkelser i Finnmark, Oppland og Sogn og Fjordane, utført med fokus på hjerte- og karsykdom (14). Utviklingen hos 40-42-åringer i Statens helseundersøkelser (SHUS) sitt 40-åringsprogram, som har vært gjennomført i alle fylker unntatt Oslo er beskrevet for tidsrommet 1974-1997 (15). Data fra senere 40åringsundersøkelser er hentet fra rapporter fra de aktuelle fylkene. Fremmøte blant 40-42-åringer sank fra $85-96$ \% i 1970-årene til rundt 80 \% i 1980-årene og videre til 50-70 \% i 1990-årene. Regionale data fra Tromsø i 1979-80 dekker aldersgrupper fra 20 til 55 år for menn og 20 til 50 år for kvinner. Tromsøundersøkelsen i 1994-95 hadde i alt 27159 deltagere fra alder 25 år og eldre og deltagelsen var $77 \%$. Undersøkelsene i Nord-Trøndelag 1984-86 (HUNT 84) og 1995-97 (HUNT 95) dekker den voksne befolkningen fra 20 års alder uten øvre aldersgrense. Fremmøtet var totalt $88,1 \%$ i HUNT 84 og $68,4 \%$ i HUNT 95 . Det var lavest hos dem over 80 år og hos 20-29åringene og høyest $\mathrm{i}$ alder 50-80 år. I alle helseundersøkelsene vi har benyttet som datakilder har fremmøtet sunket i perioden 1974-1999.

Vi har også sett på dataene fra spørreundersøkelsen Helseprofil i Akershus (17). Denne dekker aldersgruppen fra 16 til 80 år og bygger på 7697 personers egen rapport om høyde- og vektdata i 1998 . Her var svarprosenten $61,9 \%$ for menn og $69,2 \%$ for kvinner.

\section{NORSKE RESULTATER: HØYDE- OG VEKT- UTVIKLING I ETTERKRIGSTIDEN}

\section{Barn og ungdom}

I perioden 1920 til 1940 økte høyden hos skolebarn i Oslo i alder 8-14 år med $4 \mathrm{~cm}$ for hver 10-årsperiode (5). Vekten økte med 1,5 kg hos 8-åringene og opp til 3,5 kg hos 13-åringene for hver av 10-års-periodene. Under krigen skjedde en reduksjon av høydeveksten på $1,5 \mathrm{~cm} \mathrm{og} \mathrm{en} \mathrm{vektreduksjon} \mathrm{som} \mathrm{var} \mathrm{nesten} \mathrm{like} \mathrm{stor}$ som økningen i 10-årsperioden før krigen. Straks etter frigjøringen skjedde en innhenting av både høyde og vekt. Men i tiden 1950-1960 var det bare antydningsvis økning av vekten hos gutter og samtidig en tendens til lavere vekt hos jentene. Fra 1960 til 1975 gikk vekten noe ned hos både gutter og jenter under 18 år, til tross for en liten økning i gjennomsnittshøyden (5). I 1975 var gjennomsnittshøyden hos 14-åringer $164 \mathrm{~cm}$ for gutter og $163 \mathrm{~cm}$ for jenter, mens vekten var henholdsvis 50,2 og 51,2 kg. Andre undersøkelser av skolebarn viser tilsvarende resultater (6-10).

Tabell 1 viser vekt og høyde hos 13- og 18-åringer i UNGKOST i 1993. Sammenlignet med Oslo-ungdom i 1975 (5), er høyden den samme, mens gjennomsnittsvekten har økt med 4,7 kg hos gutter og 1,7 kg hos jenter (11).

Tabell 1. Gjennomsnittlig høyde, vekt og kroppsmasseindeks (KMI) hos gutter og jenter. UNGKOST 1993, selvrapporterte data (11).

\begin{tabular}{lccc}
\hline & Høyde, cm & Vekt, kg & KMI, kg/m $\mathrm{m}^{2}$ \\
\hline Gutter & & & \\
13 år & 164,9 & 52,5 & 19,08 \\
18 år & 180,6 & 72,0 & 22,06 \\
\hline Jenter & & & \\
13 år & 162,9 & 50,4 & 19,00 \\
18 år & 168,1 & 60,3 & 21,34 \\
\hline
\end{tabular}

Data for 16-19-åringer i NORKOST 1993-94 (12), viste omtrent samme nivå for høyde og vekt som UNGKOST. Blant guttene hadde $12 \%$ KMI $25 \mathrm{~kg} / \mathrm{m}^{2}$ eller høyere, og $3 \%$ ønsket å slanke seg. På den annen side ønsket $16 \%$ å gå opp i vekt. Blant jentene hadde $6 \% \mathrm{KMI} 25 \mathrm{~kg} / \mathrm{m}^{2}$ eller høyere, $35 \%$ ønsket å bli tynnere, og $2 \%$ ønsket vektøkning.

\section{Voksne}

Figur 1 viser gjennomsnittlig KMI blant 40-42-åringer i Finnmark, Oppland og Sogn og Fjordane fra 1960årene til slutten av 1990-årene $(4,15)$. Det har i hele perioden vært stigning i KMI for menn, mest markert i siste del av 1990-årene. Blant kvinner har det $i$ alle fylkene vært et U-formet forløp, med reduksjon i 1960og 1970-årene og senere stigning. Kvinnenes KMI lå i overkant av nivået hos menn i 1966-67, men dette endret seg slik at gjennomsnittlig KMI nå er langt høyere blant menn enn blant kvinner i denne alderen.

Resultater fra de norske undersøkelsene tyder på at vi må opp i stadig høyere alder for å finne høyere KMI blant kvinner enn blant menn. Data fra Finnmark i 1974-75 og 1987-88 viser at $\mathrm{i}$ den første perioden hadde kvinner $i$ alder 40 år og eldre høyere KMI enn menn, mens dette var tilfelle først etter 55 års alder $\mathrm{i}$ 1987-88 (15,17). HUNT 84 viste at kvinnenes KMI lå lavere enn hos menn før 50 års alder og høyere i eldre år, mens HUNT 95 viste at kvinnene lå lavere helt frem til 60 års alder. NORKOST 1993-94 og 1997 viser samme mønster, med lavere vekt hos kvinner enn menn før 60 års alder $(12,13)$. Helseprofilen i Akers- 
hus fra 1998 viser derimot lavere gjennomsnittlig KMI hos kvinner enn menn i alle 5-års aldersgrupper 16-80 år (16). Men forskjellen avtar og blir minimal med økende alder.

Figur 2 viser resultater for kvinner og menn fra HUNT 84 og HUNT 95 (fig 2). Nivået for KMI har steget hos begge kjønn i alle 5-års aldersgrupper fra 1984 til 1995 (3). Også NORKOST viser økning hos begge kjønn fra 1993-94 til 1997 (12).
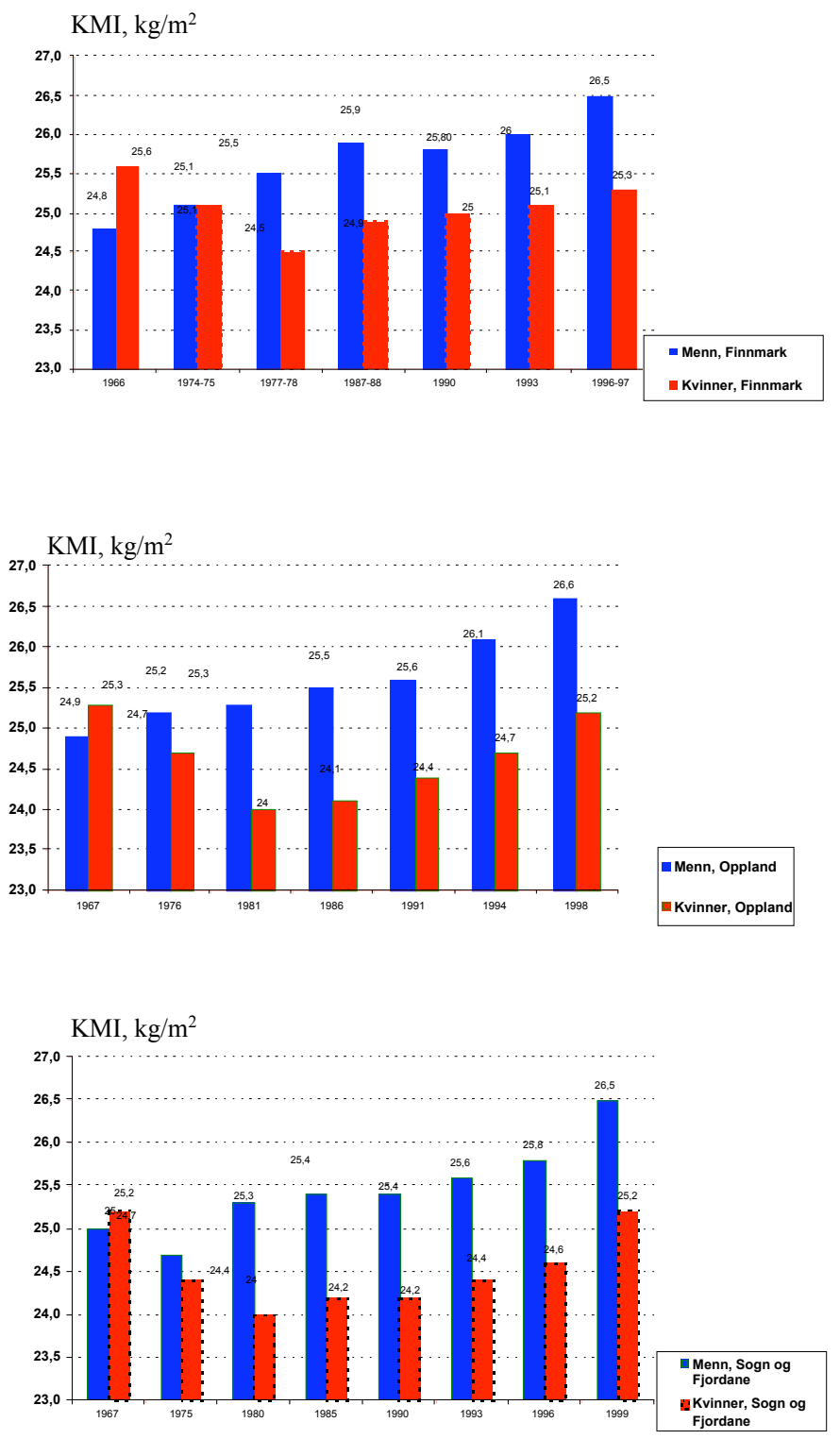

Figur 1. Gjennomsnittlig KMI $\left(\mathrm{kg} / \mathrm{m}^{2}\right)$ hos 40-42-åringer i Oppland, Sogn og Fjordane og Finnmark 1966-99.

\section{Fedme hos voksne}

De første hjerte- og karundersøkelsene i Finnmark, Sogn og Fjordane og Oppland i 1974-76 viste at fedme var mer utbredt blant kvinner enn blant menn (14). Dette gjaldt allerede fra 20-29 års alder i Finnmark og Oppland. I alder 45-49 år hadde henholdsvis 6,4 \%, 3,8 og 4,1 \% av kvinner i Finnmark, Sogn og Fjordane og Oppland KMI på $34 \mathrm{~kg} / \mathrm{m}^{2}$ eller høyere, mens tilsvarende andeler for menn var $1 \%, 0,7 \%$ og $0,9 \%$.

Data fra skjermbildeundersøkelser i 1960-årene gjør det mulig å sammenligne KMI i 1966-69 med data fra helseundersøkelsene i 1980- og 1990-årene. Andel menn i alder 20-75 år med KMI $30 \mathrm{~kg} / \mathrm{m}^{2}$ og høyere steg noe fra 1966-69 til 1984-86 og steg deretter mer markert fram til undersøkelsen i 1995-97. Andel kvinner med fedme har hatt et U-formet forløp med laveste nivå i 1984-86. Hos kvinner i alder 40-69 år var andelen med fedme høyere i 1966-69 enn i 1995-97 (Aage Tverdal, foredrag 26.01.99).

Figur 3 viser andeler med KMI $30 \mathrm{~kg} / \mathrm{m}^{2}$ eller høyere hos kvinner og menn i HUNT 84 og HUNT 95. De to undersøkelsene viser at andelene med fedme økte markert fra 1984-86 til 1995-97, og at økningen var mest markert hos unge voksne menn (3). I 1980-årene var det forholdsvis flere "fete" kvinner enn menn etter 40 års alder, og i 1990-årene var andelene med fedme større blant kvinner enn menn etter 50 års alder.

\section{Undervekt}

Helseundersøkelser av 40-42-åringer viser at andelen med KMI under $18 \mathrm{~kg} / \mathrm{m}^{2}$ var $0,2 \%$ blant menn i perioden 1963-72 og 0,1\% i perioden 1991-95. For kvinner var de tilsvarende andelene 0,7 og $0,8 \%$ (4). Nye 40-åringsundersøkelser viser at andelene med KMI på dette nivået ikke endret seg særlig i perioden 1995 til 1997.

I HUNT 95 hadde nesten $10 \%$ av kvinnene i alder 20-24 år en KMI under $20 \mathrm{~kg} / \mathrm{m}^{2}$, mens dette gjaldt 6 $\%$ av mennene (3). Disse andelene sank til et minimum på ca. $2 \%$ av kvinnene og $1 \%$ av mennene $\mathrm{i}$ alder 55-59 år, mens de så økte med alder til $4 \%$ av kvinnene og $3 \%$ av mennene i alder 80-84 år. Data fra NORKOST 1993-94 bekrefter at andelene svært slanke $\mathrm{i}$ alle aldersgrupper ligger høyere for kvinner enn for menn (12). Hele $21 \%$ av de yngste kvinnene (2029 år) hadde en KMI under $20 \mathrm{~kg} / \mathrm{m}^{2}$, mens andelen hos menn var $8 \%$. Tabell 2 viser gjennomsnitt for høyde, vekt og KMI, fordeling av KMI på ulike nivå og ønsker om endring av vekten.

\section{Sosiale og regionale forskjeller}

40-åringsundersøkelser i tiden 1994-97 viste at dess lavere utdanningsnivået var, dess høyere var gjennomsnittsverdiene både for KMI, totalkolesterol, blodtrykk og andel røykere (18). Andeler med fedme varierte på samme vis, mens andelen svært slanke var høyest hos dem med høyest utdanning. Både når det gjaldt 

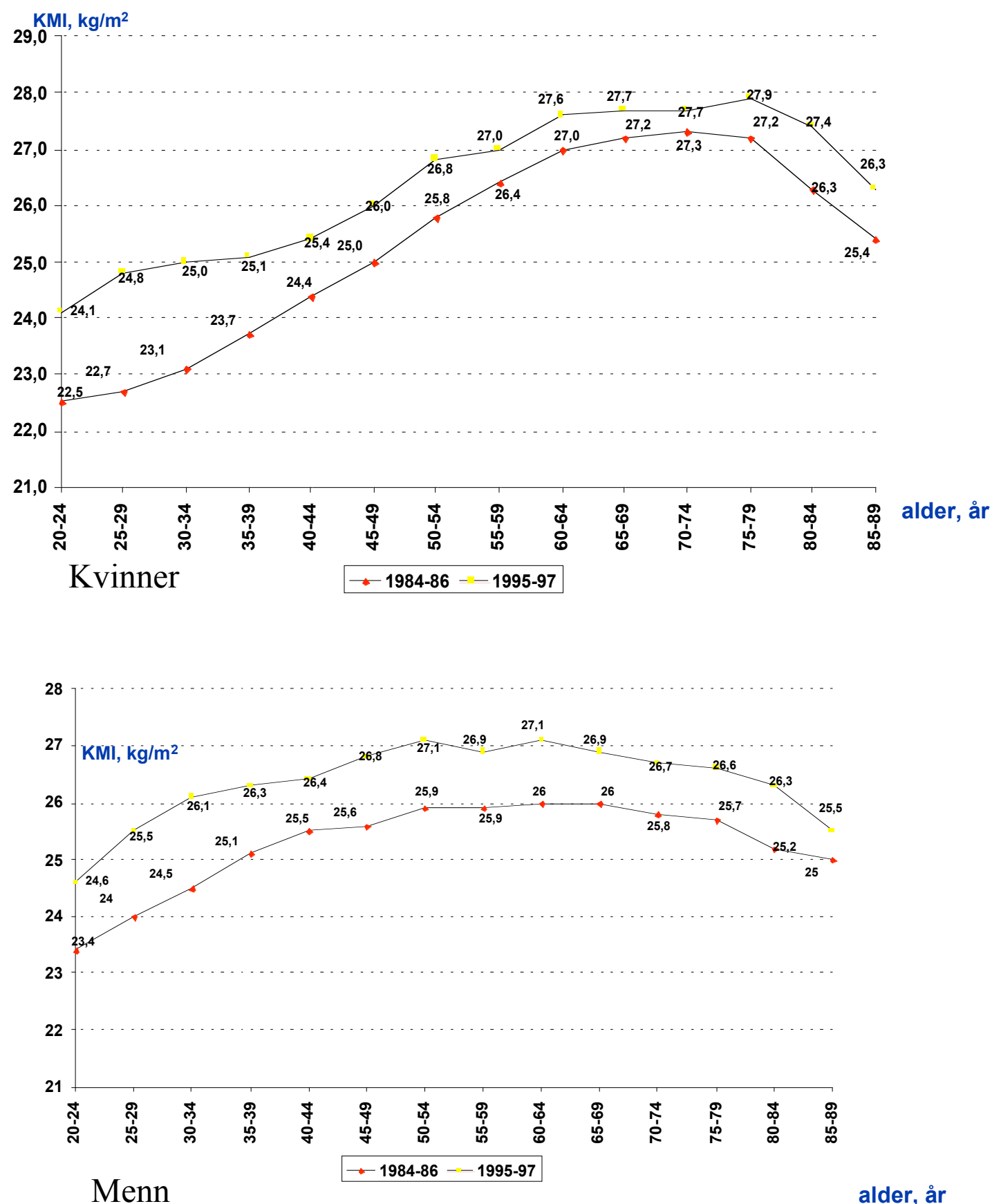

alder, år

Figur 2. Gjennomsnittlig KMI $\left(\mathrm{kg} / \mathrm{m}^{2}\right)$ hos 20-79-åringer i HUNT 84 og HUNT 95 (3).

røyking og KMI var forskjellene etter utdanning mer markerte for kvinner enn for menn.

Rapporten Helseprofil i Akershus viser hos menn i alder $25-66$ år et spenn fra $25,85 \mathrm{~kg} / \mathrm{m}^{2}$ til $25,31 \mathrm{~kg} / \mathrm{m}^{2}$ fra laveste til høyeste av tre kategorier etter utdanning og fra $25,55 \mathrm{~kg} / \mathrm{m}^{2}$ til $24,65 \mathrm{~kg} / \mathrm{m}^{2}$ fra laveste til høyeste av fem grupper etter inntekt (16). Hos kvinnene var det større spenn, fra $25,05 \mathrm{~kg} / \mathrm{m}^{2}$ til $23,25 \mathrm{~kg} / \mathrm{m}^{2}$ når det gjaldt utdanning. Men når det gjaldt inntekt var spennet heller mindre enn hos menn (fra $24,08 \mathrm{~kg} / \mathrm{m}^{2}$ i laveste inntektsgruppe til $23,36 \mathrm{~kg} / \mathrm{m}^{2}$ i høyeste). Spennet mellom gjennomsnittsverdiene i 4 regioner i fylket var for mennene fra $25,13 \mathrm{~kg} / \mathrm{m}^{2}$ i Vestregionen til $26,07 \mathrm{~kg} / \mathrm{m}^{2}$ på Øvre Romerike. Hos kvinner var spennet større, fra $23,25 \mathrm{~kg} / \mathrm{m}^{2}$ til $24,80 \mathrm{~kg} / \mathrm{m}^{2}$, og de samme regionene lå i ytterkantene.

Data fra NORKOST 1993-94 og 1997 tyder på at KMI har steget hos begge kjønn og på tvers av skillelinjer etter utdanning og både hos arbeidere og funksjonærer $(12,13)$. Det er vanskelig i dag å bruke bostedskommune som uttrykk for "by" og "land". Men kommunedataene vi har fra SHUS, tyder på et KMI er lavere $\mathrm{i}$ byer enn $\mathrm{i}$ distrikter preget av primærnæringene. 


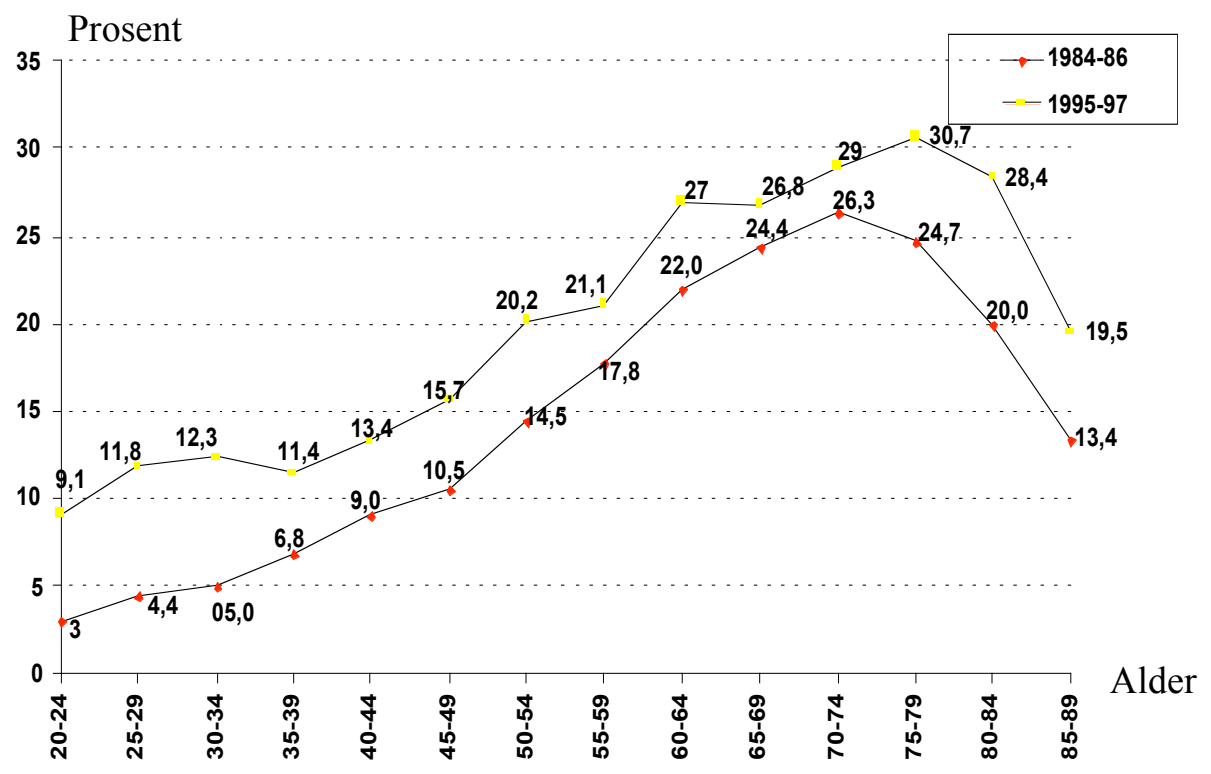

Kvinner

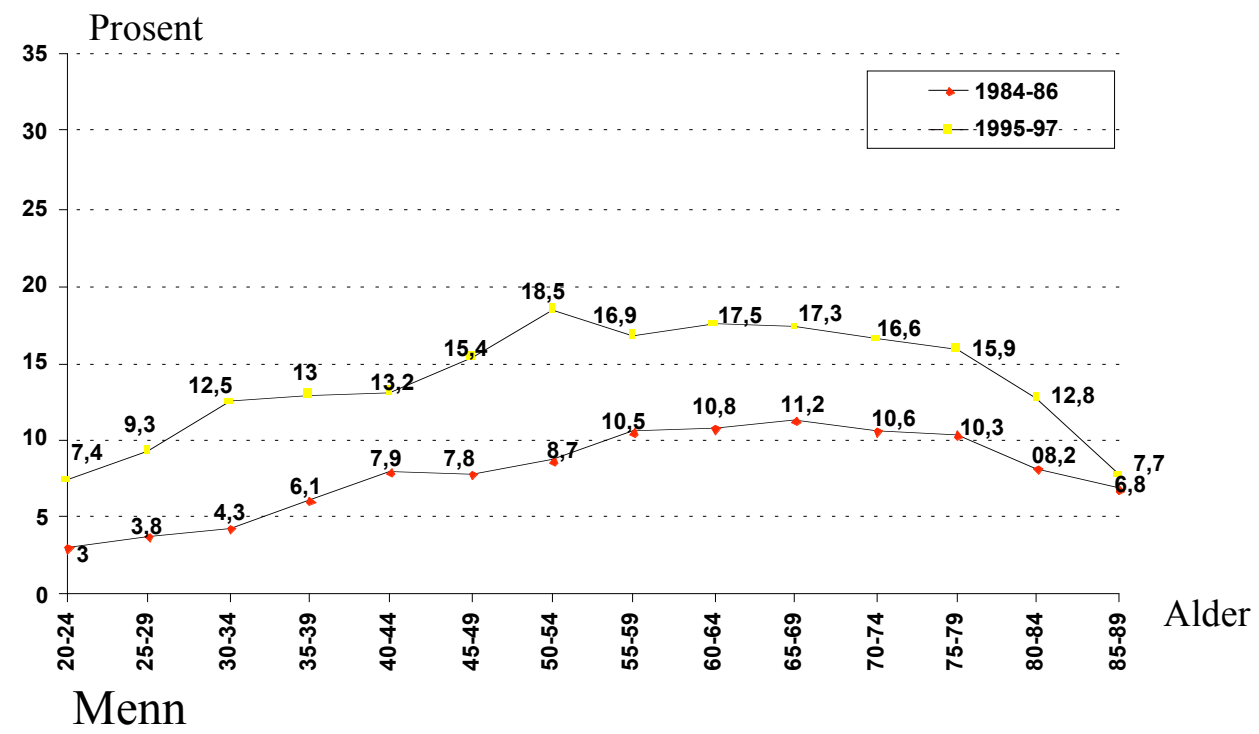

Figur 3. Andeler med KMI $>30 \mathrm{~kg} / \mathrm{m}^{2}$ hos 20-79-åringer i HUNT 84 og HUNT 95 (3).

\section{DISKUSJON}

Norske høyde- og vektdata gir godt grunnlag for å trekke slutninger om de siste 30 årene. En styrke er at de regionale studiene har hatt godt frammøte, at vektdataene er basert på måling framfor selvrapportering og at studiene er gjentatt med samme prosedyrer. Det er for øvrig konsistens mellom data fra de ulike undersøkelsene når det gjelder vekt og vektutvikling hos de to kjønn. Undersøkelsene UNGKOST, NORKOST og Helseprofil for Akershus er basert på selvrapportert høyde og vekt. Akershus-dataene skiller seg ut fra undersøkelsene som er basert på høyde- og vektmåling ved at de eldre kvinnene ligger lavere for KMI. Skyldes det at de ikke har veiet og målt seg på lenge, og dermed oppgir verdier fra yngre år? Skyldes det kanskje særlig at høyden oppgis for høy, ved at mange ikke er seg bevisst et aldersbetinget høydetap? I tillegg kommer den menneskelige tendensen til fortrenging: ikke alle ønsker å veie seg eller å huske det riktige tallet vekten viste, når vi vet at kroppsvekten er høy og for oppadgående. I følge en Willett og medarbeidere gir dette ikke vesentlige feil når det gjelder KMI (19). Men i følge Calle og medarbeidere, og også WHOrapporten, vil selvrapportering føre til for lave estimater for KMI hos overvektige $(20,1)$. 
Tabell 2. Gjennomsnitt for høyde, vekt og kroppsmasseindeks, fordeling av kroppsmasseindeks (KMI) og ønske om vektendring. NORKOST 1993-94 (12).

\begin{tabular}{l|ccccccc|ccccc}
\hline & \multicolumn{7}{|c|}{ Menn } & \multicolumn{7}{c}{ Kvinner } \\
\hline Alder & $20-29$ & $30-39$ & $40-49$ & $50-59$ & $60-69$ & $70-79$ & $20-29$ & $30-39$ & $40-49$ & $50-59$ & $60-69$ & $70-79$ \\
Antall & 269 & 330 & 296 & 221 & 149 & 107 & 369 & 321 & 289 & 202 & 166 & 116 \\
\hline Høyde & 181 & 181 & 179 & 178 & 178 & 176 & 168 & 167 & 166 & 166 & 164 & 163 \\
Vekt & 78,2 & 80,5 & 80,1 & 80,8 & 80,1 & 77,6 & 63,1 & 63,6 & 66,3 & 66,1 & 68,7 & 65,6 \\
KMI & 23,8 & 24,5 & 24,9 & 25,4 & 25,1 & 25,0 & 22,4 & 22,8 & 23,9 & 24,0 & 25,5 & 24,7 \\
\hline KMI, \% & & & & & & & & & & & & \\
$<20$ & 8 & 2 & 3 & 1 & 3 & 4 & 21 & 20 & 9 & 6 & 4 & 10 \\
$20-24,9$ & 62 & 57 & 51 & 47 & 43 & 50 & 61 & 62 & 61 & 62 & 52 & 47 \\
$25-29,9$ & 27 & 37 & 41 & 43 & 49 & 40 & 16 & 12 & 23 & 26 & 34 & 34 \\
$30+$ & 3 & 4 & 5 & 9 & 5 & 6 & 2 & 6 & 7 & 5 & 10 & 9 \\
\hline Ønsket endring, \% & & & & & & & & & & & & \\
Økning & 9 & 3 & 2 & 2 & 3 & 4 & 4 & 2 & 2 & 1 & - & 2 \\
Minskning & 18 & 22 & 23 & 17 & 26 & 10 & 37 & 34 & 44 & 39 & 42 & 28 \\
\hline
\end{tabular}

Vi har valgt konsekvent å bruke KMI fremfor andre uttrykk for kroppsfett, som midjemål og forholdet mellom midje- og hoftemål. Dette er gjort fordi det er høyde- og vektdata vi har tilgjengelig for store grupper og over tid. Men gir KMI et riktig bilde? Hos barn og tenåringer er det klart at dette ikke er tilfelle, og det finnes ingen KMI-basert standard (1). Dessuten har alder for pubertet og tilveksten i høyde etter alder endret seg gjennom den perioden vi tar for oss. Derfor baserer vi oss på høyde og vekt heller enn KMI hos unge. Men argumenter av samme type som disse, kan vel også gjelde voksne og eldre?

Willett og medarbeidere minner om at kvinner på ethvert nivå for KMI har mer fettvev enn menn (19). Det bidraget muskulaturen gir til vekten kan forklare at menn $\mathrm{i}$ enhver alder har lave andeler undervektige og høye andeler med KMI i området $25-30 \mathrm{~kg} / \mathrm{m}^{2}$. Spesielt hos unge voksne er dette aktuelt. Hadde vi hatt en enkel metode for måling av muskelmasse, ville vi kanskje benevnt en del "overvektige" unge menn med mer rosende ord. Samtidig kan det tenkes at mange av dagens "slanke" kvinner ville få merkelappen "mangel på muskulatur".

I eldre år vil ulikheter mht. tap av den fettfrie kroppsvekten $\mathrm{i}$ økende grad bidra til variasjonen $\mathrm{i}$ KMI. Tap av beinvev og andre endringer i virvelsøylen kan gi høydetap på opptil flere cm. Kvinner taper mer beinvev enn menn, og har samtidig lite muskulatur å miste. Økning av fettvev kan derfor gi stort utslag på KMI hos eldre kvinner og mindre utslag hos eldre menn.

\section{Tynne damer: skyldes det kjonnsroller?}

Både WHOs rapport, norske befolkningsundersøkelser og dessuten en rapport om vekt og vektutvikling $\mathrm{i}$ Danmark viser at kvinner i de øvre sosiale lag er slankere enn andre kvinner, mens menn i de samme lagene ikke skiller seg mye ut fra andre menn
$(1,13,21)$. Danske data viser at det er kvinner med kort utdanning som har hatt den høyeste stigningen i andelen med fedme, med hele $55 \%$ økning fra 1982 til 1992 (22). Den i utgangspunktet lavere andelen fete blant de høyest utdannede kvinnene økte ikke i det hele tatt. Samtidig var det en økning på mer enn $50 \% \mathrm{i}$ fedme hos menn med lang utdanning (22). Dette støtter den hypotesen at et slankt kroppsideal står sterkt som del av den sosiale karrieren for kvinner. Kravet til slank figur blir strengere dess høyere opp i samfunnet man aspirerer. Her kan helseinformasjonen komme inn og forsterke den tendensen skjønnhetsidealet skaper.

Blant ungdom kan det se ut til at det slanke idealet gjelder de aller fleste jenter. Kanskje er det slik at de aller fleste inntil en viss alder har et håp om en form for karriere, enten ved utdanning og egen jobb eller gjennom et parforhold som bringer velstand og lykke. En regional undersøkelse blant 8. klassinger i Kristiansand 1996 konkluderer med at mange av jentene var svært slanke, idet 30,7 \% hadde KMI $15-19 \mathrm{~kg} / \mathrm{m}^{2}$ og $58,1 \%$ lå i området $19-24 \mathrm{~kg} / \mathrm{m}^{2}$ (23). Likevel svarte nesten $30 \%$ at de opplevde seg som for tykke, og nesten $20 \%$ hadde slanket seg. Blant guttene lå også de aller fleste innen normalområdet for KMI. 4,5\% hadde KMI på $25-30 \mathrm{~kg} / \mathrm{m}^{2}$ og $0,5 \%$ hadde KMI $>30$ $\mathrm{kg} / \mathrm{m}^{2}$. Blant guttene svarte $14,9 \%$ at de opplevde seg som for tynne, 9,4\% opplevde seg som for tykke og $3 \%$ hadde slanket seg.

$\mathrm{Vi}$ vet forholdsvis lite om vektutviklingen blant barn og ungdom. Kanskje var barn og ungdom like slanke før som nå. Det nye er vel en langt større kroppsbevissthet blant barn og unge, og derav følgende ønsker om at kroppen skulle vært annerledes enn den er.

\section{Evig ungdommelig?}

Begrepene "konefasong" og "fruekjole" kan tyde på sosial aksept for at godt voksne, gifte kvinner har noen 
ekstra kilo. Men slik aksept han kanskje variere med tid og sted? Ser vi på Nord-Norge og Midt-Norge i 1970-årene var fedme mer vanlig hos kvinner enn hos menn allerede før 30 års alder (14), men i 1990-årene var det slik først ved 50 til 60 års alder i disse delene av landet. I rapporten fra Akerhus 1998, er kvinnene i gjennomsnitt slankere i alle aldersgrupper (16), og samme tendens viser danske data (22). Kanskje blir kvinner i mer urbane strøk aldri så gamle at kjønnsrollens krav slipper taket? Her må vi imidlertid huske metodeproblemet som ligger $i$ at begge de nevnte undersøkelsene var basert på selvrapportering av høyde og vekt. Og det at kvinnene er mindre fete enn mennene må sees i lys av at yngre og middelaldrende menn har økt mye i vekt de siste årene.

\section{Underernaring hos enslige gamle - et "kvinneproblem"?}

Andelene med lav KMI (under $18-20 \mathrm{~kg} / \mathrm{m}^{2}$ ) er høyere hos kvinner enn hos menn også i eldre år. På den ene side er dette ventet, ut fra kvinnenes mindre muskulatur. På den annen side kan det henge sammen med at svært mange gamle kvinner enten lever alene eller har en eldre og enda mer omsorgstrengende ektemann.

\section{Hva kan ha gitt ulik vektutvikling for kvinner og menn mellom 1950 og 1980?}

I det følgende gjør vi oss tanker om hva som kan forklare de forskjellene vi ser når det gjelder utviklingen for KMI fra $1950 \mathrm{og}$ fremover til omkring 1980. Var det en periode-effekt som rammet voksne menn, eller kanskje kvinner og ungdom selektivt? Eller ble befolkningen rammet av det samme, men på ulike tidspunkter?

Genetikk, sosiale forhold, tidlig ernæring, det daglige energiinntak og kostholdets sammensetning, fysisk aktivitet, alkoholbruk, røyking og røykeslutt står sentralt, når årsakene til vektøkning, fedme og vektreduksjon blir diskutert $(3,20)$.

Mens genene neppe er endret, har det vært ulike normer for hva som er vakkert og sunt. I dag er det vanlig å kople skjønnhet, helse og slank normalvekt sammen. Men rett etter 2. verdenskrig, da knapphet på næring var noe man fryktet eller hadde erfart, var ekstra kilo et helsegode og tegn på velstand. Selv om det ikke var sult i Oslo, har krigen ført til at skolebarns høyde og vekt stagnerte (5). Da kjøpekraften og tilgangen på fete matvarer økte i 1950- og 1960-årene, er det forståelig at KMI steg.

Først må vi spørre hvorfor mennenes vekt ikke økte til samme høye nivåer som kvinnenes rett etter krigen. Her tenker vi på to forhold: røyking og tungt arbeid. Det var svært vanlig at menn røykte i 1950-årene, mens røyking blant kvinner var lite utbredt (24). Røykere viser seg jevnlig å ha lavere vekt enn eks-røykere og ikke-røykere $(4,13)$. For tungt kroppsarbeid mangler vi data fra 1950- og 1960-årene. Men det ligger nær å anta at mange menn fremdeles hadde kroppsarbeid og at dette holdt vekten nede selv om kosten var fet.

Så er spørsmålet hva som kan ha påvirket ungdom og kvinner til vektreduksjon i 1960- og 1970-årene. Kostens sammensetning i 1950- og 1960-årene, med store innslag av hard margarin og melkefett, kan neppe ha virket slankende på noen (3). Vi vet at kvinner følger best opp de anbefalinger som gis om riktig kosthold og tar til seg mindre fett og mer frukt og grønnsaker enn mennene gjør $(12,25)$. Dette kan ha spilt en rolle etter hvert som mager kost ble promotert i 1970årene. Slankebølger og magre normer for utseende har vært i virksomhet i hele etterkrigstiden. Men sto de sterkere i 1960- og 1970-årene enn senere? Og kan bevisst slanking ligge bak den markerte nedgangen $i$ gjennomsnittlig KMI i alle aldersgrupper av kvinner i Nord-Trøndelag? Og det vi vet om mosjon skulle tilsi at menn, heller enn kvinner, tok av i vekt i 1970-årene. Stillesittende sysler fremfor mosjon i fritiden var mer vanlig for kvinner enn menn (14).

Det vi vet om røyking, kan derimot bidra til forklaring. Slutten av 1960-årene var preget av økende røyking blant kvinner i hele sju av ti femårskohorter (24). Blant kvinner født 1940-44 røykte drøyt 50 prosent $\mathrm{i}$ 1970, noe som var markert høyere enn både før og etter. Blant menn, derimot, gikk andelen røykere ned etter 1955 (24). Etterslepet i tid for den kvinnelige "røykeepidemien" i forhold til den mannlige kan derfor bidra til å forklare vekt-trendene.

Hva var det som fikk menn til å øke i vekt gjennom 1960-og 1970-årene? Utviklingen mot kortere arbeidsdag og arbeidsuke, sterk vekst $\mathrm{i}$ antallet biler, traktorer og løfteanordninger kommer inn her. Allerede i 197476 oppga $20-39 \%$ av menn i alder $20-49$ år å ha en stillesittende jobb (14). Vi har ingen dokumentasjon for andel med stillesittende jobb eller med tungt kroppsarbeid i årene før. Men det kan tenkes at mange menn etter hvert fikk lettere jobb og et energioverskudd i den grad energien i kosten ikke ble tilsvarende redusert. Husmorarbeid og annet kvinnedominerte arbeid kan ha blitt mindre og langsommere endret enn mannsyrkene. Blant kvinner var andelene med stillesittende jobb klart lavere enn blant menn i 1970-årene (14). Det kvinner og ungdom hadde felles, kan ha vært nettopp dette at få i disse gruppene opplevet endringen fra tungt kroppsarbeid til fysisk lettere arbeid. De slapp å måtte omstille seg fra et svært energirikt kosthold. Fra 1980-årene har kroppsmassen steget hos alle grupper. Dette kan passe med at teknologien ble utbredt til hele dagliglivet, slik at vi nesten alle har fătt svært lave behov for energi i kosten. Vektutviklingen viser at dette er noe vi som kultur og samfunn ennå ikke har tilpasset oss. 


\section{REFERANSER}

1. Obesity. Preventing and managing the global epidemic. Report of a WHO Consultation on Obesity. Geneva, 3-5 July 1997. WHO, 1998.

2. NOU 1999:13. Kvinners helse i Norge. Oslo: Statens forvaltningstjeneste, 1999.

3. Vekt-helse. Rapport nr. 1, 2000. Statens råd for ernæring og fysisk aktivitet, 2000.

4. Tverdal A. Høyde, vekt og kroppsmasseindeks for menn og kvinner i alderen 40-42 år. Tidsskr Nor Laegeforen 1996; 116: 2152-6.

5. Brundtland GH, Liestøl K, Walløe L. Height, weight and menarcheal age of oslo schoolchildren during the last 60 years. Ann Hum Biol 1980; 7: 307-22.

6. Waaler PE. Anthropometric studies in Norwegian children. Acta Pcediatr Scand 1983; (suppl 308): 3-41.

7. Brundtland GH, Liestøl K, Walløe L. Høyde og vekt hos skolebarn. Tidsskr Nor Laegeforen 1975; 95: 79-83.

8. Knudtzon J, Waaler PE, Solberg LK, Grieg E, Skjærven R, Steen J, Irgens LM. Høyde, vekt og hodeomkrets hos 0-4 år gamle barn. Data basert på SYSBARN-registreringen og medisinsk fødselsregister. Tidsskr Nor Logeforen 1988; 108: 2136-42.

9. Knudtzon J, Waaler PE, Skjærven R, Solberg LK, Steen J. Nye norske percentilkurver for høyde, vekt og hodeomkrets for alderen 0-17 år. Tidsskr Nor Lageforen 1988; 108: 2125-35.

10. Tell GS, Vellar OD. Physical fitness, physical activity, and cardiovascular disease risk factors in adolescents: The Oslo Youth Study. Prev Med 1988; 17: 12-4.

11. Statens ernæringsråd. UNGKOST 1993. Rapport fra Statens ernæringsråd, Oslo, 1997.

12. Statens ernæringsråd. NORKOST 1993-94. Landsomfattende kostholdsundersøkelse blant menn og kvinner i alderen 16-79 år. Rapport fra Statens ernæringsråd, Oslo, 1997.

13. Statens råd for ernæring og fysisk aktivitet. NORKOST 1997. Landsomfattende kostholdsundersøkelse blant menn og kvinner i alderen 16-79 år. Rapport nr. 2 1999, SEF, Oslo, 1999.

14. Bjartveit K, Foss OP, Gjervig T. The cardiovascular disease study in Norwegian counties. Results from the first screening. Acta Med Scand 1983; suppl. 675.

15. Bjartveit K, Wøien G. Risikofaktorer for hjerte-karsykdom i Norge. Resultater fra undersøkelser i 18 fylker. Oslo: Statens helseundersøkelser, 1997.

16. Grøtvedt L. Helseprofil i Akershus. Befolkningen svarer. HELTEF, Stiftelse for helsetjenesteforskning, Sentralsykehuset i Akershus, rapport 4-1999. Nordbyhagen, 1999.

17. Westlund K, Søgaard AJ. Helse, livsstil og levekår i Finnmark. Resultater fra Hjerte- og karundersøkelsen i 1987-88. Finnmark III. ISM skriftserie nr. 28. Universitetet i Tromsø, Institutt for samfunnsmedisin, Tromsø, 1993.

18. Graff-Iversen S. Utdanning og risikofaktorer for hjertesykdom. Norsk Epidemiologi 1998; 8 (suppl. 1): 19.

19. Willett WC, Dietz WH, Colditz GA. Guidelines for healthy weight. $N$ Engl J Med 1999; 341: 427-34.

20. Calle EE, Thun MJ, Petrelli JM, Rodriguez C, Heath CW. Body-mass index and mortality in a prospective cohort of U.S. adults. N Engl J Med 1999; 341: 1097-105.

21. Heitmann BL, Richelsen B, Hansen BL, Hølund U. Overvekt og fedme. Befolkningens sundhed set i relation til den øgende forekomst af fedme i Danmark. Rapport. Danmark: Sundhedsstyrelsen, 1999.

22. Heitmann BL. Forekomst og udvikling af overvægt og fedme blant voksne danskere i alderen 30-60 år. Ugeskr Loeger 1999; 31: 4380-4.

23. Høigaard R, Seiler HL. En kartlegging av forholdet mellom kroppsvekt og høyde blant elever i 8. klasse i Kristiansand kommune. Høgskolen i Agder, avdeling for helse- og idrettsfag, 1998.

24. Lund KE. Samfunnsskapte endringer i tobakksbruk i Norge i det 20. århundre. Oslo: Universitetet i Oslo, Institutt for medisinske adferdsfag, 1996.

25. Kvaavik E, Meyer HE, Selmer RM, Egeland G, Tverdal A. Kostvaner i Hedmark i forhold til kjønn, utdanning og sivilstand. Tidsskr Nor Lageforen 1999; 119: 3406-9. 